\title{
MACHADO, IDA LUCIA; MELLO, RENATO DE (ORGS.). ANÁLISES DO DISCURSO HOJE, VOLUME 3. RIO DE JANEIRO: NOVA FRONTEIRA/ LUCERNA, 331 PÁGINAS, 2010.
}

\author{
Resenhado por Cássio Eduardo Soares Miranda ${ }^{1}$ \\ (Universidade Federal de Minhas Gerais - UFMG)
}

"A inércia é o meu ato principal". Esta instigante frase do poeta Manoel de Barros pode ser tomada como ponto de partida para a leitura do mais recente livro organizado pelos Professores Ida Lucia Machado e Renato de Mello do Núcleo de Análise do Discurso da Faculdade de Letras da UFMG. Podemos dizer que o «ato principal», nesta coletânea, traduz-se pelo tecer, pois é no próprio alinhavo dos textos que nela são apresentados que os autores reconstróem, costuram e desvelam as marcas e os fios constitutivos dos discursos contemporâneos a partir de uma variedade de teorias sobre a análise do discurso na atualidade.

Ancorado no rigor de sua argumentação, na potencialidade de sua análise e no vasto e profundo conhecimento do tema, o livro refere-se à um conjunto de textos produzidos por autores brasileiros e estrangeiros envolvidos no ensino e pesquisa da linguística do texto e do discurso em diversas universidades brasileiras e européias, que se colocaram a trabalho no intuito de desvelar suas práticas e demonstrar as incidências da análise do discurso no que tange ao ensino, à pesquisa e à prática dos estudos da linguagem nos dias de hoje.

Sabemos, a partir da psicanálise, da sociologia e da filosofia, que o tempo presente caracteriza-se por um imperativo categórico do gozo, em que os ideais contemporâneos são marcados por uma lógica do consumo. Da mesma forma, os diversos discursos circulantes na sociedade têm demonstrado que o surgimento de novas demandas, principalmente aquelas marcadas pela lógica supracitada, comparecem, nos diferentes discursos, como "novas modalidades"

1. Pós-doutorando em Análise do Discurso pela UFMG, sob coordenação da professora Dra. Ida Lucia Machado. Bolsista da FAPEMIG. 
de estudá-los. É com base, de certo modo, em tal constatação, que certamente Machado e Mello propuseram aos diferentes autores da coletânea, a possibilidade de construir uma abordagem dessas manifestações pautada não apenas em uma política de classificação e tipologia dos discursos, mas, antes, em um tipo de construção teórica que leva em consideração as múltiplas manifestações dos sujeitos do discurso. Curiosamente, o livro encontra sua maior força graças a esta bem cuidada "sedimentação" em artigos: o grupo de dezessete pesquisadores discorrendo sobre corpora diversos, escolhendo a "prática discursiva" como "motor e mola" de seus artigos vai dar a necessária coerência à coletânea.

Com muita propriedade, os organizadores do livro, conscientes de que, em geral, o aparato teórico sobre a Análise do Discurso tem encontrado uma variedade imensa de temas produzidos, conseguem assim evitar as armadilhas de uma visão catalogalizante, atentos às íntimas relações entre saber e poder que se estabelecem e se reproduzem no seio da própria linguagem: o livro pretende não apenas mapear o território discursivo, mas antes, busca apresentar "uma reflexão sobre os diferentes ethé que são expostos ou dissimulados pelos diferentes sujeitos-comunicantes ou enunciadores, bem como o papel das emoções e da argumentação na construção de diferentes discursos", como é dito no Prefácio da obra. Da apresentação desses elementos, contribuições e reflexões é que emerge o traço minucioso da Análise do Discurso atual, alicerçada em uma prática contemporânea que apresenta o sujeito em suas mais variadas manifestações.

Em um primeiro momento, os organizadores propõem uma discussão a partir do ethos contemporâneo e o que ele pode ensinar ao analista do discurso de hoje. Sabemos que o interesse crescente pelo ethos está ligado a uma evolução das condições do exercício da palavra publicamente proferida, ou seja o ethos é estudado pelos analistas do discurso do ponto de vista de sua inserção pragmática nos discursos cotidianos atuais. Se o ethos é um dos paradigmas da $\mathrm{AD}$ atual, os autores aqui concernidos apóiam-se em fatos discursivos para fazer valer suas discussões, seja no âmbito de uma prática, seja no âmbito de uma pesquisa teórica propriamente dita. Tentaremos 
melhor explicar este pensamento citando a seguir dois trabalhos entre os outros -todos excelentes e originais, diga-se de passagem - apenas para melhor ilustrar o que foi até agora por nós afirmado. Em primeiro lugar, o texto de Maingueneau (Paris XII) apresenta as diferenças e aproximações entre o ethos literário e o ethos publicitário: os dois éthé inscrevem-se em uma proposta de uma "apresentação de si" em que se pode perceber como é grande a porosidade "[...] entre o discurso literário e o discurso publicitário, mas também esses discursos e outros, que, no entanto, não temos o hábito de relacionar com eles". Em segundo lugar, Vaz (FAFICH/UFMG) afirma que as emoções suscitadas nos sujeitos interpretantes são o resultado de um conjunto de estratégias desenvolvidas pelos sujeitos comunicantes e, no caso do objeto "revista", elas se dão através da associação de elementos gráficos, icônicos e textuais: "[...] se há lugar a ser explorado na mídia impressa para despertar tantas emoções erotizadas, certamente deve haver lugar para expressar outros sentimentos que despertem outras emoções", diz o autor em pauta.

Aliás, no âmbito dos estudos sobre éthé são bastantes valiosas e instigantes as contribuições de Kerbrat-Orecchioni (Lyon III), Lopes (PUC/MG), Monnerat (UFF), Pauliukonis (UFRJ) e Siess (Univ.de Caen). Cada um com suas especificidades e aplicações, tais autores ampliam nossos conhecimentos sobre o assunto.

Na obra ora resenhada são muitos os pontos a se destacar. Por exemplo, acreditamos que é a primeira vez que é publicado, no Brasil um artigo como o de Bacot (Lyon III) que trata dos "agorônimos" vistos como discurso argumentativo. Por se constituir como resultado de pesquisas e da experiência de um grupo de professores-pesquisadores participantes do III Colóquio Internacional sobre Análise do Discurso, a obra difunde, pois várias perspectivas que solidificam a união "AD \& teorias argumentativas": isso pode ser visto, por um lado, através dos escritos de Wander Emediato (UFMG) e João Bôsco Cabral dos Santos (UFU); por outro lado, na lembrança da "força dos estereótipos na argumentação" (cf. Lysardo-Dias).

Outras perspectivas aparecem na coletânea. Assim, as emoções (como um todo) são abordadas pelo viés de um outro caminho ou 
vertente dos estudos discursivos (a Semiótica) em um texto "a duas vozes" realizado por Lara e Matte (UFMG). A presença provocante dos "desafios" da cognição no campo da $\mathrm{AD}$ também se faz ver na coletânea através dos textos escritos por Mari e Matêncio (PUC/MG). Do mesmo modo, é sempre interessante e enriquecedor ver como a Retórica atua no campo discursivo: é disso que fala o texto de Danblon (Univ. Livre de Bruxelas). Finalmente, a psicologia social, sempre "boa companheira" de metodologias de AD, como a Semiolinguística, se faz ver no artigo assinado por Chabrol e Diligeart (Paris III) e perpassa o instigante trabalho de Charaudeau (Paris XIII) que, neste livro, trata do tema: a propaganda como tipologia.

Enfim, em seu todo, a coletânea apresenta-se como uma leitura imprescindível para estudantes e pesquisadores das mais variadas disciplinas/cursos que têm a linguagem e o discurso como um de seus campos de atuação e ou manifestação.

Assim, se "No osso da fala dos loucos têm lírios", como sustenta o nosso já citado poeta (Manoel de Barros) no "osso" da prática discursiva cotidiana também os "lírios" podem ser encontrados e, pode-se dizer, esta obra constitui-se como tal.

Recebido em: agosto de 2010 Aprovado em: outubro de 2010 cassio.edu2007@gmail.com 